\title{
Critical by design?
}

An Introduction

Claudia Mareis,

Moritz Greiner-Petter

\& Michael Renner 
The relationship between design and critique remains as ambiguous and conflicting as ever. It is a problematic relationship which seems to be full of irresolvable contradictions and for that very reason it can be seen as a productive one, too.' The ambiguity we are referring to is historically grounded and systemically anchored, yet it is open to change and transformation. The history of the design discipline as a modernist profession, mostly envisioned from Europe and North America, closely related to industrial production, nationalist politics and mass communication, is deeply interwoven and still highly complicit with exploitative and unequal processes of creation, production and consumption. As a consequence, and as an ongoing manifestation of the "darker side of Western modernity» (Mignolo 2011), ${ }^{2}$ the history and practice of design is infused with very specific, but also very limited Anglo-Eurocentric ideas about «universal» design and exclusive aesthetic preferences, with the perpetuation of unsustainable lifestyles, exuberant consumer cultures and capitalist value structures.

At the same time, this history has been marked by numerous attempts to tie together the logics and needs of design, technology and society in critical, speculative and utopian ways and change design from within. Starting with the socialist utopias of the Arts \& Crafts movement in the 19th century (see Kaplan 2004), the vision of the Bauhaus in uniting art and technology at the beginning of the 20th century (see Droste 2019), the Italian Radical Design movement in the post-war period (see Sparke 2014; Didero 2017), or the school of Critical and Speculative Design (Dunne [1999] 2005; Dunne/Raby 2001) at the turn of the new millennium - to name just a few. Recent calls for a decolonization of design (Abdulla 2018; Escobar 2018; Schultz et al. 2018; Vieira de Oliveira / Prado de O. Martins 2019; Ansari 2021a), however, made clear that as much as these and other critical design movements have been thought to change the world from within design, they have hardly ever been able to overcome their Anglo-European biases.

These examples from Bauhaus to Critical Design show the ambiguity and compromises omnipresent in the tense relation between design and critique. As much as design has been instrumentalized to cement the socio-political and commercial status quo and project it into the future, there has always been the desire and hope that the same practices and concepts could be reframed, reimagined and 
converted to critique the present and propose alternative futures. Just as inequality, injustice and exploitation are all too often established and perpetuated by means of design, there is also an ongoing claim to critically uncover, dismantle and reconfigure these conditions through or with design: through or with critical design practices, methods, histories, manifestos or attitudes. Critical practice, in the words of design researcher Ramia Mazé, is often regarded as «a kind of «criticism from within design - that is based on and carried out by design means, by designers and by means of their own practical and operational modes» (Mazé 2016: para. 1). Cause, criticism and measures appear to be closely linked here. However, it remains a virulent question as to how the language, logics and materialities of design, the epistemological baggage of the discipline, and the methods, approaches and strategies within design practice itself can be thought of and implemented as a mode and vehicle of critique. The answers and positions in this regard are constantly shifting and require disentangling and rethinking. In this process, design is, more or less obviously, also changing its roles, scope and influence in ever more comprehensive social, cultural, political and professional contexts, practices, systems and discourses. "Critical by Design?» is a question to which there is no unambiguous answer, but many different, even contradictory suggestions.

This anthology brings together interdisciplinary perspectives and new impulses for the discussion and advancement of criticality in design. The contributions offer investigations into design as a mode of critique from various backgrounds and positionings towards the discipline, from design studies and history to design practice and education as well as philosophy, art history and theory, and informatics. The interrogative notion of the title «Critical by Design?» carries throughout the book. It is a genuine questioning, neither neglecting nor readily affirmative of the critical potentials of design. It is a careful, but by no means exhaustive attempt to consider in more detail from which positionalities and framings notions of criticality in design can be legitimately and productively conceptualized, how specifically critique has to be fashioned and articulated under the conditions and modes of operation of design, and how our understandings and vocabularies of critique and critical practices can be diversified and expanded. As such, the contributions in this volume are not primarily trying to provide best practices of critical design approaches, but are sharing this questioning and interrogative attitude, each in their own way trying to open up new spaces, vocabularies or frames of reference to think about critique and criticality in design.

Therefore, in the very beginning, it is necessary to turn the gaze of critique inward, as self-critique. Although we have striven to create 
a volume of diverse intellectual positions and practices, we acknowledge that the variety of authors we have brought together is nonetheless limited. The positions that are voiced here represent predominantly Western European and Anglo-American perspectives, written by a predominantly white group of peers. As such, this volume by no means offers a comprehensive insight into the debates around design and critique; nor is it a representative depiction of the diversity of actors in the field. Through the work on this book, we have learned that our mandate for the future is to cultivate more diverse and inclusive academic productions and cultures, and to actively acknowledge, reroute and relinquish the privileges of economics and exposure in ways that allow for systemically underrepresented voices to be heard. These comments are not meant to diminish the value of the chapters presented here, but rather to make clear the situated perspective from which many of these authors speak, including the offers and limitations that come with them.

\section{What design, what critique?}

If design is understood, in an ontological perspective, as a reciprocal mode of socio-material world-making and "coming into being» (Fry 2012), ${ }^{3}$ then the power and scope of design seem almost unlimited and so does its harmful potential. Richard Sennett, among other cultural scholars, has pointed out not only the outstanding civilizational achievements of human making, but also the destructive sides connected to it: «Material culture provides in sum a picture of what human beings are capable of making. This seemingly limitless view is bounded by selfinflicted harm whether occurring innocently, by intent, or by accident» (Sennett 2008: 15). In other words: human making, including design culture ${ }^{4}$ comprises the totality of Promethean power (Latour 2009), it is both farsighted and destructive. Making new devices, objects and technologies is like opening Pandora's Box: once created and in the world, artificial things create a life of their own, which does not always correspond to what their creators had hoped for.

From the times of industrial production to contemporary digitalization, many design practitioners, historians and educators have dealt with these double-edged effects of design. They have been driven by a concerned awareness of the destructive violence potentially underlying every creative act and they have struggled with the asymmetric power structures in the design world or with the harmful effects of mass consumption on the environment. Widely known is the bold 
accusation made by Victor Papanek in the 1970s, when he spoke out against the design profession:

There are professions more harmful than industrial design, but only a very few of them. And possibly only one profession is phonier. Advertising design, in persuading people to buy things they don't need, with money they don't have, in order to impress others who don't care, is probably the phoniest field in existence today. Industrial design, by concocting the tawdry idiocies hawked by advertisers, comes a close second. (Papanek 1973: 14)

At the same time, however, he also took an affirmative position by advocating a positive mode of design and seeing the possibility of designing social justice and change: "As socially and morally involved designers, we must address ourselves to the needs of a world with its back to the wall while the hands on the clock point perpetually to one minute before twelve» (Papanek 1973: 14). Papanek's example, which itself became the subject of criticism (see Clarke 2021), illustrates that the trajectories of invention, production, consumption and destruction, in which design is historically and systemically involved, reflect existing socio-political constraints as well as future spaces of imagination and utopian world views. Design transforms what it touches and is itself always already shaped by history, genealogy and context. The question of design is, as Tony Fry has noted, "always an ontological question», while at the same time design is "a domain of metaphysical knowledge», in that it "always arrives as the way something acts as, in and on the world, and as a learnt thinking (theory) that informs practices which bring something into being» (Fry [1999] 2020: 4).

Seen in this light, design critique, especially critical design practice, harbours the hope for transformation and change, while it also carries existing presuppositions and epistemic contradictions within itself. It promises to actively bring forth new visions of life and society and to build bridges between past, present and future times, while at the same time often failing to extricate itself from the entanglements of history. In the German expression entwerfen (designing), which goes back to the Latin word projicere (to throw something away or in front of oneself), design's promise to open up futures is very aptly expressed. In the act of designing, ideally a new space for thought and action should be opened - open for both utopian visions and critical distance. Not only design but also critique are presented here as temporal modes of thinking through making, as "a reflective disposition towards the present as a fleeting now that opens up to an unknown future», as sociologist Andreas Folkers (2016: 7) puts it. At the same time, this disposition contains not only reflective but also 
diffractive properties (Haraway 1997; Barad 2007), ${ }^{5}$ as Folkers further emphasizes:

"Critique is not just a reflection that leaves what it reflects upon unaltered, but a diffraction ... that changes what is put under critical scrutiny» (Folkers 2016: 19). Simply put, critique changes what it touches. It is a practice of sounding out the limits of knowledge and truth and thus changing them.

According to French philosopher Michel

Foucault, from whom this idea derives, critique must be seen as something essentially relative and contradictory; as a symptom of incomprehensibility and uncertainty, and at the same time as an attempt to make this uncertainty graspable and controllable. Critique therefore refers to what is coming, what is possible, what has been passed over and what has been missed out. As Foucault wrote: "Critique only exists in relation to something other than itself: it is an instrument, a means for a future or a truth that it will not know nor happen to be, it oversees a domain it would want to police and is unable to regulate» (Foucault [1997] 2007: 42).

Critique, in other words, is a way of dealing with uncertainty and of regaining agency. The project of critique ties in closely with traditions of knowledge about the future: forecasting, projections, prognosis, utopianism or even prophecy (see Bühler/Willer 2016; Weidner / Willer 2013). Because future is absent and can only be thought of as imagined, there is, and always has been, a strong need for ways and means to make it manifest through images, media, models and simulations (Bühler/Willer 2016: 9) - in short, through design. The numerous critical movements and projects in the history of design might be seen from this perspective: As hopeful attempts to sound out the limits of design's own scope of knowledge and action while at the same time providing efficient modes of grasping uncertain futures through careful consideration, creative imagination and material investigation. In this sense, the German design scientist Horst Rittel had already stated many decades before:

Designing is plan-making. Planners, engineers, architects, corporate managers, legislators, educators are (sometimes) designers. They are guided by the ambition to imagine a desirable state of the world, playing through alternative ways in which it might be accomplished, carefully tracing the consequences of contemplated actions. (Rittel 1988: 1)

In this tradition - that is, in the tradition of the «Western» Design Methods Movement (see Cross 1993; Bayazit 2004) - numerous scholars 
have described how design can be seen as a mode of tackling «wicked problems» (Rittel/Webber 1973), of "[d]ecision making in the face of uncertainty with high penalties for error» (Morris Asimov, quote in Jones 1966: 296) or as the "will to design» in order to create resilient systems, behaviours and futures (Grove 2018; see also Cowley 2017).

However, the idea of design as a general mode of problem solving is clearly limited and has been repeatedly questioned and problematized in recent years (Dorst 2006; Kimbell 2011, 2012; Mareis / Paim 2021). The more we understand how much the dominant notions of design in history and theory, in education and practice have been shaped and constrained by particular concepts and understandings of design (Euro- and androcentric, technoscientific, economic), the clearer it becomes how limited these ultimately are. Both design and critique must therefore be seen and problematized as forms of situated knowledge (Haraway 1988), shaped by and confined to specific contexts, persons and situations. The interests and motivations behind design and critique are therefore just as questionable as the conditions and possibilities under which design and critique can or cannot take place.

\section{Crisis and oritique}

There is a strong, not just etymological, nexus, between the two terms critique and crisis (Kosellek 1988). In the sense that crisis is considered a critical moment that defines the future; a moment from which on things develop either for the better or the worse and a call to action is made. But this call to action, however urgent, is rarely unambiguous or free of tension.

In crisis and critique, decision and distinction meet. They have in common the moment of divorce, of separation. Here as there, self-evident things are suspended. Crisis and critique are connected, but also conflict with each other. The art of distinction precedes the decision, but cannot help complicating it and moving away from it. Crisis challenges action, critique comes out of direct action. (Thomä et al. 2015: 14, translated by the editors)

On the other hand, this also means that simply speaking of a crisis urges action, even though there may not be an acute need for intervention.

But what does the nexus of crisis and critique mean in times like ours, in which crises are no longer decided and resolved at one point, but rather become the normal state of affairs? How is our ability to distinguish and decide appropriately affected when various crises financial crises, environmental crises, crises of democracy and social 
justice, health crises, such as the Covid-19 pandemic - interact in complex ways and reach planetary scale? Finally, what does the strong nexus of crisis and critique and the apparent normalization of crises mean for the field of design? Against this backdrop, Adam Nocek and Tony Fry, in their introduction to Design in Crisis (2021: 4), not only ask «how the planetary crisis puts design itself in crisis», but argue that "design is immanent to crisis». Design in the modernist tradition, they argue, uis at the ontological root of the universalisms responsible for the asymmetrical forms of violence that human and non-human life are facing today and in the future» (Nocek/ Fry 2021: 2). The crisis-like condition of the present must thus be seen as a "consequence of a long and violent history of privileging an Anglo-Eurocentric subject of Reason to the detriment of other ways of thinking, feeling, and living» - with design being responsible «for the fabrication of the rational technocratic human whose ambitions have put life on this planet in jeopardy» (Nocek / Fry 2021: 10).

So, what remains to be done in light of this devastating diagnosis? Is the approach of «unlearning and relearning design» (Tlostanova 2021) the only way out of the crises caused by design? Is it the radical rejection and declassification of hegemonic Anglo-Eurocentric design concepts in favour of other forms of thinking and practising design that have been marginalized, ignored or forgotten so far? The Colombia-based industrial designer Alfredo Gutiérrez (2021: 60) has formulated the dynamic interplay of un- and relearning design as follows: "The End Of The Design As We Know It (Teotdawki) goes with The Opening Of Design As We Ignore it (Tootdawii)..1 ${ }^{6}$ This statement allows, as Gutiérrez stresses, several interpretations about what exactly is to be ended and what to be opened. However, what is needed, he says, referring to Zimbabwean academic Cetshwayo Zindabazezwe Mabhena, is a «border thinking (and feeling) $»^{7}$ in order "to overcome at once fundamentalism of both worlds - the hegemonic and the peripheral ones»: "Border thinking to live in any territory without epistemically dwelling in it as fundamentalism» (Gutiérrez 2021: 61).

Another proposal to escape «the matrix of domination» (Hill Collins 2000) and to make design more just and sensitive towards intersectional discrimination (Crenshaw 1991) has been recently presented by nonbinary, transgender, femme presenting design researcher Sasha Costanza-Chock. Based on the principles of the Design Justice Network, ${ }^{8}$ Costanza-Chock argues for using design «to sustain, heal, and 
empower our communities, as well as to

8 http://designjusticenetwork.org.

seek liberation from exploitative and oppres-

sive systems» (Costanza-Chock 2020: 6).

The principles of design justice include, among others, to «prioritize design's impact on the community over the intentions of the designer» and to «work towards sustainable, community-led and controlled outcomes» as well as «non-exploitative solutions that reconnect us to the earth and to each other» (Costanza-Chock 2020: 6f). This raises questions about both the status of designers and design expertise, as within the Design Justice Network the role of the designer is seen "as a facilitator rather than an expert» and the lived experience of those who are touched by design issues in some way is enhanced: "We believe that everyone is an expert based on their own lived experience, and that we all have unique and brilliant contributions to bring to a design processı (Costanza-Chock 2020: 7).

To return to the nexus of crisis and critique, one could subsequently also ask here: is it not necessary, as a matter of urgency, to question and situate, to end and open up the modes of critique uas we know them» in order to create space for "other», that is, more just and diverse ways of thinking and critiquing? What would these ways look like; and what would be the consequences?

\section{Critique of critique}

This anthology is also characterized by the awareness that the very notion of critique has been critically questioned and expanded for quite some time. This is not only the case in the humanities and social sciences, but also in the field of design. The idea that design is just a supplier for industrial production or, in a more advanced understanding, a knowledge-based problem-solving activity has increasingly become blurred by the questioning of design-immanent paradigms, privileges and beliefs. For a long time, many design scholars saw the greatest potential of design in its ability to improve people's living conditions and to solve complex problems - independent of the problem or context. As stated above, this view has been repeatedly questioned and problematized in recent years, as it is often based on asymmetrical power-knowledge structures and false universalist ideas of design, knowledge, technology and progress. This is done, for example, by making it seem normal that design experts from the Global North devised solutions to the problems of the Global South (see Messell 2021); or by an unquestioned colonialist / orientalist attitude, in declaring one's own practices to be particularly progressive by neglecting, devaluing or romanticizing the «other». In this context, Ahmed Ansari has pointed out that many of the key texts of 
the Design Methods Movement «were deeply orientalist» in «how they relied on defining the field along very explicit distinctions between (modern) Western societies that developed «design) against «traditional) societies that practiced (craftı» (Ansari 2021b: 96).

Against this background, projects from the field of Critical and Speculative Design, although they might appear less «solutionist» or "affirmative» at first sight, were also problematized because of their unquestioned Eurocentric and colonial biases. By discussing concrete examples from the field of Critical and Speculative Design, Pedro J.S. Vieira de Oliveira and Luiza Prado de O. Martins (2019) have shown how much the speculative visions of the future are shaped by the sociocultural background of the designers creating these visions, and how little the Eurocentric view - the colonial «gaze» - often underlying them is questioned: "There is no space for questioning where that scenario came from, what sequences of events preceded it ... There is only space for one narrative - the one devised by the designer; no rough edges, no place for those who cannot afford to have their stories up for display» (Vieira de Oliveira and Prado de O. Martins 2019: 107). In contrast, "that speculation needs to be enacted in transient spaces in which any perspective could become a loose thread for exploring the future or an amalgamation of untold pasts and uncertain presents» (Vieira de Oliveira / Prado de O. Martins 2019: 109).

Ramia Mazé believes that, instead of being «concerned with problem-solving», critical design practice should rather be about «problem-finding» (Mazé 2009: 381). This means that critical design practice should be about fundamentally questioning problem definitions and problem-solving approaches with regard to their inherent political interests and seeing things in a larger historical and systemic context. As a consequence of this suggestion, research and research-related methodologies are becoming increasingly important for the design discipline and critical design practice (see Mazé / Redström 2007). Also, design is moving closer to the humanities and their tradition of genealogical self-questioning, problematization and critique. At the same time, it must be added, Anglo-Eurocentric discourses and traditions of critique are often perpetuated.

In the humanities, the question of critique is profoundly linked to epistemological, ethical and political considerations on the limits of knowledge/truth as well as to the relation between self-determination and governance (see Foucault [1997] 2007). At the same time, the notion of critique has been associated from within and outside the humanities with a judgemental, distanced view - as something that can be destructive rather than constructive. The examination of critique thus refers to different aspects, modes and levels of impact. It is a question of how and through what media, formats and practices 
critique is expressed (e.g. philosophical texts, artistic manifestos, provocative images, speculative design objects, disobedient behaviour etc.). Moreover, it is about a sensitivity to the convictions of knowledge and truth, of distance and commitment, which underlie the various critical traditions in the sciences, humanities, the arts and design. Many scholars consider the seductive idea that critique would «expose» or «reveal» something hidden as too simplistic, as is the idea that critique could be formulated "from the outside», unaffected by what is criticized.

«The narrative of theoretical unravelling, of being undone is a journey of phases in which the thought we are immersed in is invalidated», Visual Culture scholar Irit Rogoff argues (2003). Critique, or better yet criticality, as she defines it (Rogoff 2003), is thus not necessarily characterized by analytical distance or theoretical superiority, but rather by the unique opportunity of embodied involvement, by bringing together «that being studied and those doing the studying, in an indelible unity» (Rogoff 2006). "[I]t is not possible to stand outside of the problematic and objectify it as a disinterested mode of learning", Rogoff explains; rather it is "a state of duality in which one is at one and the same time, both empowered and disempowered, knowing and unknowing» (Rogoff 2006). Accordingly, criticality cannot arise simply by adding something new to existing knowledge, but it is, again, about the painstaking process of un- and relearning. Rogoff explains this point as follows: "Criticality) as I perceive it is precisely in the operations of recognising the limitations of one's thought for one does not learn something new until one unlearns something old, otherwise one is simply adding information rather than rethinking a structure» (Rogoff 2003).

Michel Foucault, who has worked comprehensively on the genealogy of critique and has taken a political position himself, reminded us that a critique that carries weight is always associated with a personal risk for the critic. Critique is not something for which one needs to ask permission, he argued, but an act of self-empowerment. Following him, critique must be regarded as «the movement by which the subject gives himself the right to question truth on its effects of power and question power on its discourses of truth» (Foucault [1997] 2007: 47).

Ultimately, one needs to realize that any critique, however wellintentioned and well-grounded it might be, at some point can turn against itself. It is also sometimes forgotten that the same critique, for example the critique of the state, can be expressed from different sides and with different intentions: by neoliberal as well as by anarchist voices (Foucault 2008). Critique thus definitely has a life of its own, which sometimes goes beyond what once was intended, and it might also include more and other meanings than are explicitly expressed. 
Against this background, it makes sense to see critique as something that potentially creates diversity and multiplicity. "What would critique do if it could be associated with more, not with less, with multiplication, not subtraction», sociologist Bruno Latour asked in view of the problem that, of all things, the critical attitude of science ultimately plays into the hands of science sceptics (Latour 2004: 248). He is concerned with the fact that critique too often damages and diminishes things instead of making them productive. We would like to transpose this concern to the field of critical design practice: what might a contemporary critical design practice look like that is committed, involved, courageous and robust, but is not so elitist, naive and short-sighted as to be misused and turned against itself?

\section{On design as critical material practice}

One aspect that has been important for the conception of this anthology is the question of the different embodiments and socio-material entanglements of design as critical material practice. Many of the following chapters deal with this idea of practical, materialized critique. Whereas in the humanities critique is usually expressed in the form of language and text (which obviously also have a practical and material dimension), in the field of design we can observe a trend to exercise critique in an explicitly embodied and materialized way: through interventions in urban spaces, speculative design objects, fictional film scenarios or thought-provoking images. One driving idea behind materialized critique is that designed artefacts consist of a symbolic-material dimension that triggers both action and thought; that they have an «evocative» character (Turkle 2007). Through their particular usability, readability or affordability, critical objects or critical artefacts, as they might be called, enable access to certain insights, things, spaces and functions and in turn exclude others (see Helvert/ Bandono 2016). They aim to challenge and question prevailing views on body, gender, culture and social class and attempt to counter them with new perspectives. The idea that the symbolic-material dimension of design can trigger both action and thought is not only currently driving many design scholars and practitioners, but was adopted (at least partially) by earlier critical design movements. For example, within the semiotically oriented design groups around Ettore Sottsass in Italy (Sparke 2014; Didero 2017) or in the school of Critical and Speculative Design founded by Anthony Dunne and Fiona Raby (Dunne [1999] 2005; Dunne/Raby 2001). However, critical material practice in design is not only about the role and meaning of finished artefacts in their use, but also about the ways of producing them; that is, the activity of inventing, designing and manufacturing. In short, it's about 
the process of "thinking through making», as the anthropologist Tim Ingold calls the complex interplay between maker, material and situation (Ingold 2013). A very similar view on design, although stated earlier and against a different background, was suggested by sociologist Donald Schön. He described design as «conversation with the materials of a situation»: "[The designer] shapes the situation in accordance with his initial appreciation of it, the situation (talks back), and he responds to the situation's back-talk. In a good process of design, this conversation with the situation is reflective» (Schön 1983: 78f.).

On the one hand, the trend of seeing design as a critical material practice draws on historical traditions and models in the field of design history itself (such as the few examples mentioned above). On the other hand, however, it also benefits from the fact that an awareness of non-textual - that is, visual, material or embodied forms of knowledge production and critique - has been created in the humanities in the decades that have passed. Since the debates around the «linguistic turn» (Rorty 1967) in the humanities in the course of the 20th century it has become clear that the generation and dissemination of knowledge is not only conditioned and limited by language, but is also shaped by media and images, instruments and tools, spatial and material constellations (see Mareis/Windgätter 2013).

The concept of «cultural techniques», for example, coined by an interdisciplinary group of German scholars, follows this critique on language primacy. This concept focuses especially on those practices, techniques and forms of representation which, alongside language, are important for the systematic genesis and analysis of cultural orders and for knowledge-generation processes (Krämer/Bredekamp 2003: 11; see also Winthrop-Young et al. 2013; Siegert 2015). It assumes that culture is not only constituted by language and thought, but also by materiality, cultural techniques and epistemic procedures, such as the practical handling of pictures, sketches, models, diagrams or plans (Krauthausen 2010; Wittmann 2012). Also, the scholars involved in the areas of Image Studies and Visual Culture Studies base their projects precisely on these assumptions (see Mitchell 1994; Boehm 1994; Renner 2011). Cultural techniques, design included, are thus acknowledged to be powerful language alternatives in the process of generating and disseminating knowledge.

Although design researchers do not refer often to the mentioned humanities concepts, many related debates within the field are heading in a similar direction. "Design has its own distinct sthings to know, ways of knowing them, and ways of finding out about themın, claimed design researcher Nigel Cross (1982: 221). Design knowledge, according to him, is manifested through "people, processes and products» (Cross 2006: 101). His colleague Bruce Archer, who coined the telling 
expression "designerly ways of knowing», described design research as «systematic enquiry whose goal is knowledge of, or in, the embodiment of configuration, composition, structure, purpose, value and meaning in man-made things and systems» (Archer 1981: 31). For them and many other design researchers, design represents an independent but often neglected area of practical making and material epistemology that is not covered by the natural sciences and humanities. They see design rather as a practical knowledge culture in its own right, dealing with "the man-made world» and artificial systems (see Cross 1982: 221f.). (Although nowadays, against the backdrop of the Anthropocene crisis, we can hardly distinguish any longer between natural and artificial systems.)

In our opinion, this view of design is reflected in many of the debates about design as a critical practice. As much as we agree with the assertion that knowledge production is a deeply practical and socio-material matter, we also believe that the idea of critical objects and artefacts in design as well as the general praise of practice should be reconsidered in some respects. On the one hand, we see that designers are often still not reflecting critically enough on their own role in shaping the world and society, be it by under- or overestimating their influence, agency or privileges. On the other hand, we believe that the idea that only designers produce critical objects or artefacts blurs the fact that there are many other (both human and non-human) actors involved in shaping and reshaping the world in material ways. As Horst Rittel put it, «Everybody designs sometimes; nobody designs always. Design is not the monopoly of those who call themselves idesignersı" (Rittel 1988: 1). By this he meant that design is a specific way of thinking and acting that is not found only within design disciplines in the narrower sense, but in numerous other fields of practice too. To this view, which is still strongly influenced by the premises of the "Western» design methods movement, we would like to add that it is not sufficient to simply extend the boundaries of design to different fields of practice or contexts of application. What seems to be much more necessary is different ways of looking at design that are more diverse and inclusive, that no longer start from a narrow image of «the human», and that also consider non-human actors (materials, animals, plants) as co-creators within the design process.

Moreover, the desire for a practical change or effect of design critique sometimes has a blind spot, we feel, that manifests itself in some unquestioned biases of designing and making. As numerous authors in this anthology argue, the question of power and agency in and through design currently presents itself against the background of decolonial, queer-feminist, new materialist and ecological debates 
as something that urgently requires revisions. For too long, the discipline has struggled with an understanding of design (and designers) as anything but diverse and inclusive. The many problems with which design has to struggle today are far from being solved - let alone comprehensively understood (Mareis / Paim 2021). In view of the continuing crisis of the present, it is all the more urgent that we ask ourselves what understanding of design we want to criticize and want to cultivate. For too long design has been complicit in exploiting both natural resources and human labour, and ignoring the diversity of both human and non-human actors. Just as in other domains of thinking and acting, designers need to learn and develop «sympoietic practices for living on a damaged planet» (Haraway 2017: M31; see also Haraway 2016: chapter 3).

In addition to the current challenge of rethinking design as a radically diversified and sympathetic form of making between humans and more-than-human beings, there are other concerns too. One that we would like to share is the concern that the potential of artistic activism and critique (from which design historically often benefited) seems to be increasingly incorporated and subdued by the «new spirit of capitalism» (Boltanski / Chiapello 2005). Following the authors Luc Boltanski and Eve Chiapello, every creative act or artistic expression, however innovative, rebellious or critical it may seem, is eventually transformed into a consumable product or service. In the logic of late capitalist and neoliberal markets, creativity has long since ceased to be a unique characteristic reserved for artists and designers, but has become an encompassing social imperative that affects all professional groups equally (Reckwitz 2017). This includes not only the constant pressure to reinvent and change things, but also the acceptance of flexible - that is, precarious - working conditions and uncertain, project-based employment (Raunig et al. 2011). In this constant field of tension between resistance, innovation and commercialization, the numerous approaches to design as critical material practice must also be situated. Again, a similar question to that already asked above applies here: what might contemporary critical design practices look like that include creativity and material making in post-human (Forlano 2017) and more-than-human worlds (Puig de la Bellacasa 2017) but are not so solution-oriented and pseudo-innovative that they can easily be instrumentalized and turned against themselves?

As already emphasized at the beginning of this introduction, the aim of this anthology is not to provide ready-made answers, but to bring together a variety of voices and various perspectives around the question of Critical by Design? 
The volume is structured into three main parts - Genealogies, Practices and Positions. These primarily act as thematic reading guidance, while by no means trying to mark definite categorizations or clear-cut divisions. In fact, many of the contributions address and approach their respective subjects in ways that expand across and beyond the proposed notions of the sections. They nonetheless offer a set of larger framings in order to shift attention to certain domains or positionalities from which the chapters can be read and approached.

We consider Part I, Genealogies, foundational in character in a number of ways. Contributions in this part variously retrace conceptual filiations and histories of notions of critique within design and their influences on discourse and practice in the field. They furthermore begin to unpack essential assumptions and epistemes of the discipline of design to displace the vantage points for critical engagements to more fundamental levels of the conditions and epistemological genealogies of the field. In their different focuses, the chapters in this part also map out a range of ways to approach the capacities of critique within design across varying and equally crucial scales, spanning from the level of the artefactual or the critical object to the politics of design.

Design theorist and historian Annette Geiger opens the section with her chapter "What is a critical object? Design as (desubjugation) (after Foucault)», in which she lays out how Foucault's understanding of critique, unlike critical design's often misleading references to critical theory, offers an appropriate understanding of the critical and emancipatory potential of designed things.

In «The vitality of the negative: critical design between social philosophy and conceptual art» design and art historian Emanuele Quinz retraces the genealogies of fundamental theoretical contexts of critical thinking and practices in design and reconstructs the negation of functionality, commodification and usefulness as an influential conceptual model for critical design strategies.

In his detailed philosophical analysis «Ask what can be! Modal critique and design as drivers of accidence», Bruno Gransche shows how critique and design share a transformative power in relation to the modal sphere of the possible, that is also the sphere of accidence. He argues for a modal design that assumes responsibility for the often unintended side effects of every act of designing - the structuring of the space of possibility.

In «What are the politics of ontological design? A critical reflection on the mutual becoming of (the humans and (the world»), design researcher Michaela Büsse thoroughly examines the concept of Ontological Design and points out design politics as a blind spot that 
is indispensable to appropriately study and characterize contemporary forms of design.

Design philosopher Mara Recklies asks in «Engaging in epistemic disobedience: on the decolonialization of design discourses» what it would entail to deconstruct and disobey the deep coloniality of the epistemic foundations, knowledge cultures and ideologies of the design discipline, a challenging endeavour not without its own inherent contradictions.

Part II, Practices, brings together contributions more distinctly oriented towards, informed by and reflecting on critical design in and as practice. Without neglecting questions of materialization, aesthetics and form-giving, the contributions nevertheless share a deliberate shift of attention to the conditions and performance of design practice itself as a mode of critique. They collectively ask how practices need to be extended, reframed and reconfigured to allow for novel and effective forms of practising and articulating critique to emerge.

Anja Groten reflects on her own practice as designer, educator and community organizer as part of the collective Hackers \& Designers. In «Unsettling individualized design practice through collaboration», she discusses situations of collaborative making as social prototypes and sites of friction for probing and challenging notions about individual and collective design and knowledge practices.

In «ICi concimiamo a vicendar: building support structures as part of design practice», a conversation between Meike Hardt and Bianca Elzenbaumer, the two designers and design researchers discuss the economic conditions and cultivated work ethics of design practice itself as a field for creative intervention and critical reconfiguration.

Patrycja Zdziarska, Jeffrey Bardzell and Shaowen Bardzell, humanistic researchers in Informatics and Human-Computer Interaction, adopt the feminist concept of «Re-Vision» as a productive analytical framework for design criticism. In «Re-visioning pelvic care through design», they show how differing design approaches that address a shared issue can perform critically on different scales and to varying degrees.

In «Trojan horses: ambiguity as a critical design strategy», Emile De Visscher, researcher and practitioner with a background in design and engineering, argues for a promising space of critical design approaches that effectively bridge the distinction between affirmative, functioning or solution-oriented operation on the one side, and critical, reflective or speculative dimensions on the other.

Similarly, in "Grey design: critical practices of design at the peripheries of the discipline», designer and design researcher Moritz Greiner-Petter proposes to diversify understandings of the forms 
critical design projects can take and to shift the attention to practices that operate in expanded contexts, where the boundaries of what is recognized as designing are questioned.

Part III, Positions, brings together chapters that are, to various extents, more speculative in character in the way they project and propose new trajectories for critique. These contributions probe the grounds for innovative approaches to critical practices, transfer notions of criticality between the fields to offer new perspectives for design, and take on and develop distinct critical positions and attitudes.

Janneke Wesseling introduces notions of critique from the perspective of art theory and discusses the critical potential of «The ineliminable aesthetic dimension of art». Illustrated by the practices of three artists, she proposes «deictic explanation» as a specific materialdiscursive gesture of artworks.

Design researcher and practitioner Guy Julier, who established Design Culture as an academic field of enquiry that studies the interconnections between design, production and consumption - the relationality of objects, social and material processes - asks what it could mean to understand «Design culture as critical practice».

Designer and researcher Carl DiSalvo, in asking «What might be the speculative social?», is proposing a novel mode of practice by critically reassessing and bringing together the fields of Speculative Design, Social Design and Participatory Design.

In «Undesign and understanding», designer and design theorist Björn Franke offers the concept of «undesign» as a critical lens, form of inquiry and practice that aims at questioning and undoing adverse ideologies deeply held within the design discipline.

In light of the inevitable political dimension of any design activity and design's enduring and historically elusive claims of neutrality and objectivity, designer and design educator Jesko Fezer argues in «Biased design, or the misery of neutrality» for the need for an emphatically political design attitude.

Lastly, as an epilogue to the volume, Matt Ward reflects on his extensive experience as a design educator and practitioner in his very personal account of «The life and death of critical and speculative design: post-disciplinarity, post-truth, post-self and post-capital», weaving together a thoughtful retrospective with prospects for more caring, sustainable and self-reflective cultures of design practice and teaching. 
The production of this volume as well as the preceding conference and research project were supported by the Swiss National Science Foundation. We are grateful to transcript for their support and the promotion of open access publishing. We wish to thank the reviewer for their invaluable time and extensive feedback on the manuscript. Great thanks go to Meike Hardt and Marius Förster for their work on the multifaceted design concept and layout of the publication and their reflective approach to rendering issues of criticality into a design language. An extended commentary by the two designers on the thinking process behind the design of the publication is included in the Appendix. We also want to particularly thank Meike Hardt for her invaluable support in coordinating the publication. We further thank Ludwig Zeller for his significant work on the early concept, preparation and co-editing of the volume. Philipp Bräuner supported us in editing and preparing the manuscript. Translations were done by Adam Blauhut (Chapters 5, 7 and 14) and James Gussen (Chapter 2). Joan Dale Lace was responsible for the copy editing of the manuscript. Lastly, we want to express our gratitude to all the contributing authors for their enriching and dedicated work and their generous time and patience throughout the publication process. 
Abdulla, Danah (2018): «Design Otherwise: Towards a Locally-Centric Design Education Curricula in Jordan.» PhD thesis, Goldsmiths, University of London.

Ansari, Ahmed (2021a): «Design's Missing Others and Their Incommensurate Worlds.ı In: Adam Nocek/Tony Fry (eds.), Design in Crisis. New Worlds, Philosophies and Practices, New York: Routledge, pp. 137-157.

Ansari, Ahmed (2021b): «W/hite Supremacy and Epistemic Colonialism in Design Discourse, Scholarship, \& Practice: A Basic Primer.. In: Rhys Atkinson/Rachel Jung / Riccardo Righi (eds.), A Line Which Forms a Volume 4, London: London College of Communication, pp. 95-102.

Anzaldúa, Gloria E. (1987): Borderlands / La Frontera: The New Mestiza, San Francisco, CA: Aunt Lute. Archer, Bruce (1981): «A View on the Nature of Design Research.» In: Robin Jacques/James A. Powell (eds.), Design, Science, Method: Proceedings of the 1980 Design Research Society Conference, Guildford: Westbury House, pp. 30-47.

Barad, Karen (2007): Meeting the Universe Halfway: Quantum Physics and the Entanglement of Matter and Meaning, Durham, NC/London: Duke University Press.

Bardzell, Jeffrey / Bardzell, Shaowen / Blythe, Mark A. (2018): Critical Theory and Interaction Design, Cambridge, MA: MIT Press.

Bayazit, Nigan (2004): «lnvestigating Design: A Review of Forty Years of Design Research.» Design Issues 20/1, pp. 16-29.

Boehm, Gottfried (1994): «Die Wiederkehr der Bilder.» In: Gottfried Boehm (ed.), Was ist ein Bild?, Munich: Fink, pp. 11-38.

Boltanski, Luc/Chiapello, Eve (2005): The New Spirit of Capitalism, London: Verso.

Bühler, Benjamin / Willer, Stefan (2016): «Einleitung.» In: Benjamin Bühler/Stefan Willer (eds.), Futurologien: Ordnungen des Zukunftswissens, Munich: Fink, pp. 9-21.

Christensen, Michelle / Conradi, Florian (2020): Politics of Things: A Critical Approach through Design, Basel: Birkhäuser.
Clarke, Alison J. (2021): «Design for the Real World: Contesting the Origins of the Social in Design.» In: Claudia Mareis/Nina Paim (eds.), Design Struggles. Intersecting Histories, Pedagogies, and Perspectives, Amsterdam: Valiz, pp. 85-98.

Costanza-Chock, Sasha (2020): Design Justice: Community-led Practices to Build the Worlds We Need, Cambridge, MA: MIT Press.

Cowley, Robert (2017): «Resilience and Design: An Introduction..s In: Robert Cowley/Clive Barnett/Tania Katzschner / Nathaniel Tkacz / Filip De Boeck, Forum: Resilience \& Design, Resilience 6/1, pp. 1-34.

Crenshaw, Kimberlé Williams (1991): «Mapping the Margins: Intersectionality, Identity Politics, and Violence Against Women of Color.. Stanford Law Review 43/6, pp. 1241-1299.

Cross, Nigel (1982): «Designerly Ways of Knowing.» Design Studies 3/4, pp. 221-227.

Cross, Nigel (1993): «A History of Design Methodology.» In: Marc J. de Vries / Nigel Cross / D. P. Grant (eds.), Design Methodology and Relationships with Science, Dordrecht: Springer, pp. 15-27.

Cross, Nigel (2006): «Design as a Discipline.» In: Designerly Ways of Knowing, London: Springer, pp. 95-103.

Didero, Maria Cristina (ed.) (2017): Superdesign: Italian Radical Design 1965-75, New York: Monacelli Press.

Dorst, Kees (2006): «Design Problems and Design Paradoxes.» Design Issues 22/3, pp. 4-17.

Droste, Magdalena (2019): Bauhaus. Updated edition, edited by Bauhaus-Archiv Berlin, Cologne: Taschen.

Dunne, Anthony (2005 [1999]): Hertzian Tales: Electronic Products, Aesthetic Experience, and Critical Design, Cambridge, MA: MIT Press.

Dunne, Anthony/Raby, Fiona (2001): Design Noir: The Secret Life of Electronic Objects, London/Basel: August/Birkhäuser.

Dunne, Anthony / Raby, Fiona (2013): Speculative Everything: Design, Fiction, and Social Dreaming, Cambridge, MA: MIT Press.

\section{References}


Escobar, Arturo (2018): Designs for the Pluriverse: Radical Interdependence, Autonomy, and the Making of Worlds, Durham, NC/London: Duke University Press.

Fisher, Tom / Gamman, Lorraine (eds.) (2019): Tricky Design: The Ethics of Things, London: Bloomsbury.

Folkers, Andreas (2016): «Daring the Truth: Foucault, Parrhesia and the Genealogy of Critique.» Theory, Culture \& Society 33/1, pp. 3-28.

Forlano, Laura (2017): «Posthumanism and Design.» She Ji: The Journal of Design, Economics, and Innovation 3/1, pp. 16-29.

Foucault, Michel (2007 [1997]): «What Is Critique?» In: Silvère Lotringer (ed.), Michel Foucault: The Politic of Truth, Los Angeles: Semiotext(e), pp. 41-81.

Foucault, Michel (2008): The Birth of Biopolitics: Lectures at the Collège de France, 1978-1979, New York: Palgrave Macmillan.

Fry, Tony (2012): Becoming Human by Design, Oxford: Berg Publishers.

Fry, Tony (2020 [1999]): Defuturing: A New Design Philosphy, London: Bloomsbury.

Geerts, Evelien / van der Tuin, Iris (2016): «Diffraction \& Reading Diffractively.» July 27, 2016, https://newmateri alism.eu/almanac/d/diffraction.html.

Grove, Kevin (2018): Resilience, London: Routledge.

Gutiérrez, Alfredo (2021): «When Design Goes South: From Decoloniality, through Declassification to Dessobons.») In: Adam Nocek / Tony Fry (eds.), Design in Crisis: New Worlds, Philosophies and Practices, London: Routledge, pp. 56-73.

Haraway, Donna J. (1988): «Situated Knowledges:

The Science Question in Feminism and the Privilege of Partial Perspective.») Feminist Studies 14/3, pp. 575-599.

Haraway, Donna J. (1997): Modest_Witness@Second_Millennium. FemaleMan@_Meets_OncoMouse ${ }^{\mathrm{TM}}$ : Feminism and Technoscience, New York: Routledge.

Haraway, Donna J. (2016): Staying with the Trouble: Making Kin in the Chthulucene, London: Duke University Press.
Haraway, Donna J. (2017): «Symbiogenesis, Sympoiesis, and Art Science Activisms for Staying with the Trouble.» In: Anna Tsing / Heather Anne Swanson/Elaine Gan / Nils Bubandt (eds.), Arts of Living on a Damaged Planet, Minneapolis / London: University of Minnesota Press, pp. M25-M50.

Helvert, Marjanne van / Bandono, Andrea (2016):

The Responsible Object: A History of Design Ideology for the Future, Amsterdam: Valiz.

Hill Collins, Patricia (2000): Black Feminist Thought: Knowledge, Consciousness, and the Politics of Empowerment, 2nd ed., New York: Routledge. Ingold, Tim (2013): Making: Anthropology, Archaeology, Art and Architecture, London / New York: Routledge.

Jones, John Christopher (1966): «Design Methods Reviewed.» In: Sydney A. Gregory (ed.), The Design Method, London: Butterworths, pp. 295-309.

Julier, Guy (2019): Design Culture: Objects and Approaches, London: Bloomsbury.

Kaplan, Wendy (ed.) (2004): The Arts and Crafts Movement in Europe and America: Design for the Modern World, London: Thames \& Hudson.

Kimbell, Lucie (2011): «Rethinking Design Thinking: Part I.» Design and Culture 3/3, pp. 285-306.

Kimbell, Lucie (2012): «Rethinking Design Thinking Part II.» Design and Culture 4/2, pp. 129-148.

Koselleck, Reinhart (1988): Critique and Crisis: Enlightenment and the Pathogenesis of Modern Society, Cambridge, MA: MIT Press.

Krämer, Sybille/ Bredekamp, Horst (2003): «Wider die Diskursivierung der Kultur: Zur Einleitung in diesen Band.» In: Sybille Krämer / Horst Bredekamp (eds.), Bild, Schrift, Zahl, Munich: Fink, pp. 11-22.

Krauthausen, Karin (2010): «Vom Nutzen des Notierens: Verfahren des Entwurfs.ı In: Karin Krauthausen/Omar W. Nasim (eds.), Notieren, Skizzieren: Schreiben und Zeichnen als Verfahren des Entwurfs, Zurich: Diaphanes, pp. 7-26. 
Latour, Bruno (2004): «Why Has Critique Run out of Steam? From Matters of Fact to Matters of Concern.» Critical Inquiry 30 , pp. 225-248.

Latour, Bruno (2009): «A Cautious Prometheus: A Few Steps Toward a Philosophy of Design (with Special Attention to Peter Sloterdijk).» In: Jonathan Glynne / Fiona Hackney/Viv Minton (eds.), Networks of Design: Proceedings of the 2008 Annual International Conference of the Design History Society (UK), Falmouth, 3-6 September, Boca Raton, FL: Universal Publishers, pp. 2-10.

Malpass, Matthew (2017): Critical Design in Context: History, Theory, and Practices, London: Bloomsbury. Manzini, Ezio (2015): Design, When Everybody Designs, Cambridge, MA: MIT Press.

Mareis, Claudia/ Paim, Nina (eds.) (2021): Design Struggles: Intersecting Histories, Pedagogies, and Perspectives, Amsterdam: Valiz.

Mareis, Claudia/ Windgätter, Christof (eds.) (2013): Long Lost Friends: Wechselbeziehungen zwischen Design-, Medien- und Wissenschaftsforschung, Zurich/Berlin: Diaphanes.

Mazé, Ramia (2009): «Critical of What? / Kritiska mot vad?» In: Magnus Ericson / Martin Frostner / Zak Kyes / Sara Teleman/Jonas Williamsson (eds.), Iaspis Forum on Design and Critical Practice - The Reader, Berlin: Sternberg Press, pp. 378-397.

Mazé, Ramia (2016): «Design Practices Are Not Neutral.» May 4, 2016, http://speculative.hr/en/ramia-maze/.

Mazé, Ramia/Redström, Johan (2007): «Difficult Forms: Critical Practices of Research and Design..» In: Proceedings of the IASDR Conference on Design Research, Hong Kong, http://www.sd.polyu.edu.hk/ iasdr/proceeding.

Messell, Tania (2021): «Sustainable Design on the World Stage: The International Council of Societies of Industrial Design and Environmental Concerns, 1970-1990..) In: Claudia Mareis / Nina Paim (eds.), Design Struggles: Intersecting Histories, Pedagogies, and Perspectives, Amsterdam: Valiz, pp. 101-115.
Mignolo, Walter D. (2011): The Darker Side of Western Modernity. Global Futures, Decolonial Options, Durham, NC/London: Duke University Press.

Mignolo, Walter D. / Tlostanova, Madina V. (2006): "Theorizing from the Borders: Shifting to Geo- and Body-Politics of Knowledge.» European Journal of Social Theory 9/2, pp. 205-221.

Mitchell, William J. T. (1994): Picture Theory: Essays on Verbal and Visual Representation, Chicago: Chicago University Press.

Nocek, Adam / Fry, Tony (2021): «Design in Crisis, Introducing a Problematic.ll In: Adam Nocek / Tony Fry (eds.), Design in Crisis: New Worlds, Philosophies and Practices, London: Routledge, pp. 1-15.

Papanek, Victor (1973): Design for the Real World: Human Ecology and Social Change, Toronto et al.: Bantam Books.

Puig de la Bellacasa, Maria (2017): Matters of Care: Speculative Ethics in More Than Human Worlds, Minneapolis: University of Minnesota Press.

Raunig, Gerald/Ray, Gene/Wuggenig, Ulf (eds.) (2011): Critique of Creativity: Precarity, Subjectivity, and Resistance in the "Creative Industries», London: May Fly.

Reckwitz, Andreas (2017): The Invention of Creativity: Modern Society and the Culture of the New. Translated by Steven Black, Cambridge: Polity Press.

Renner, Michael (2011): «Die stumme Bildkritik des Entwurfs - The Mute Iconic Criticism of Design.» Rheinsprung 11. Zeitschrift für Bildkritik, Basel: eikones, pp. 92-116.

Rittel, Horst W. J. (1988): «The Reasoning of Designers.» Working Paper from the International Congress on Planning and Design Theory in Boston 1987. Schriftenreihe des Instituts für Grundlagen der Planung, Universität Stuttgart, pp. 1-9.

Rittel, Horst W. J./Webber, Melvin M. (1973): «Dilemmas in a General Theory of Planning.» Policy Sciences 4, pp. 155-169. 
Rogoff, Irit (2003): «From Criticism to Critique to Criticality.» transversal 8/6, eipcp - European Institute for Progressive Cultural Policies, https://transversal.at/transversal/0806/rogoff1/en.

Rogoff, Irit (2006): «(Smuggling) - An Embodied Criticality.» eipcp - European Institute for Progressive Cultural Policies, http://xenopraxis.net/readings/rogoff_smug gling.pdf.

Rorty, Richard (1967): The Linguistic Turn: Recent Essays in Philosophical Method, Chicago: University of Chicago Press.

Schön, Donald A. (1983): The Reflective Practitioner: How Professionals Think in Action, New York: Basic Books.

Schultz, Tristan / Abdulla, Danah / Ansari, Ahmed / Canlı, Ece/Keshavarz, Mahmoud/Kiem, Matthew/Prado de O. Martins, Luiza/Vieira de Oliveira, Pedro J. S. (2018): "What Is at Stake with Decolonizing Design? A Roundtable.» Design and Culture 10/1, pp. 81-101.

Sennett, Richard (2008): The Craftsman, New Haven, CT / London: Yale University Press.

Siegert, Bernhard (2015): Cultural Techniques: Grids, Filters, Doors, and Other Articulations of the Real, New York: Fordham University Press.

Sparke, Penny (2014): «Ettore Sottsass and Critical Design in Italy, 1965-1985.» In: Grace Lees-Maffei/Kjetill Fallan (eds.), Made in Italy: Rethinking a Century of Italian Design, London: Bloomsbury, pp. 59-72.
Thomä, Dieter / Festl, Michael G. / Grosser, Florian (2015): «Einstimmung: Vier Etappen der Geschichte von Kritik und Krise.» In: Michael G. Festl/Florian Grosser / Dieter Thomä (eds.), Über Krise und Kritik, Studia Philosophica 74, Basel: Schwabe, pp. 11-18.

Tlostanova, Madina (2021): «Unlearning and Relearning Design.» In: Adam Nocek/Tony Fry (eds.), Design in Crisis: New Worlds, Philosophies and Practices, London: Routledge, pp. 163-180.

Turkle, Sherry (2007): Evocative Objects: Things We Think With, Cambridge, MA: MIT Press.

Vieira de Oliveira, Pedro J. S. / Prado de O. Martins, Luiza (2019): «Designer/Shapeshifter: A Decolonizing Redirection for Speculative and Critical Design.» In: Tom Fisher / Lorraine Gamman (eds.), Tricky Design: The Ethics of Things, London: Bloomsbury, pp. 103-114.

Weidner, Daniel/Willer, Stefan (eds.) (2013): Prophetie und Prognostik: Verfügungen über Zukunft in Wissenschaften, Religionen und Künsten, Munich: Fink.

Willis, Anne-Marie (2006): «Ontological Designing.» Design Philosophy Papers 4/2, pp. 69-92.

Winthrop-Young, Geoffrey / Iurascu, Ilinca / Parikka, Jussi (eds.) (2013): «Cultural Techniques.» Theory, Culture \& Society 30/6, Los Angeles: Sage.

Wittmann, Barbara (2012): «Papierprojekte. Die Zeichnung als Instrument des Entwurfs.» Zeitschrift für Medienund Kulturforschung 3/1, pp. 135-150.

Tharp, Bruce M. / Tharp, Stephanie (2019): Discursive Design: Critical, Speculative, and Alternative Things, Cambridge, MA: MIT Press.

Thierfelder, Jana (2014): Perspektiven des Critical Design: Evolutionary Past - Symbiotic Future, Stuttgart: Merz-Akadamie. 
